根性坐骨神経痛に対する立位硬膜外造影法の検討

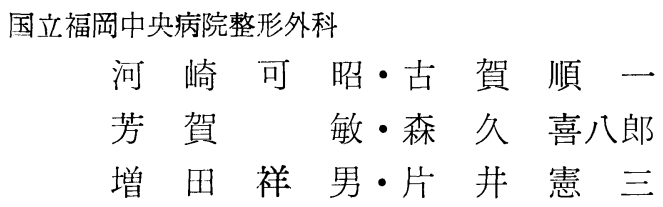

\title{
Peridurography by Up-right Position
}

By

\author{
Y. Kawasaki. J. Koga, B. Haga, K. Morihisa, \\ S. Masuda \& K. Katai
}

Orthopedic Surgery of the National

Fukuoka Central Hospital

In 66 cases of low back pain with or without sciatica, peridurography using $60 \%$ Urographin had been made by upright position since July in 1970, in National Fukuoka Central Hospital.

An advancement of this method was to be able to prove more exactly the existence of the disk herniation owing to recognition of the fine picture in lumbar peridural space than by prone position.

The findings of these peridurographs were on the whole same as those of the operations.

In case of the so-called central herniation, because of the symptomless of the sciatica; the herniation is found out only by this peridurography.

We reported the results of six typical cases.

腰椎椎間板へルニアについては, 臨床的には, 脊椎 の変形, 神経根伸展症状, 知覚障害の部位, 腱反射の 異常, 坐骨神経に沿う压痛, 笳萎縮, 筋力低下, など を参考にして診断を行うが, 必らずしもてれらの条件 をすべて満足するわけではない．またその高位診断に ついては, 知覚障害の部位, 腱反射, 筋力減退, など を参考にするが，教科書によっては，それぞれ異った 意見が述べられて抢り，一定した見解は得られていな い. このような見地から，種々の検查法か開発されて 来たが，その中で障害の少ない水溶性造影剂による硬 膜外造影法が, 最近注目されて来ている. しかし，そ の方法によっては，必らずしあ明確な所見が得られな いあのである. そてで私達は, 従来のような腹臥位に おいて造影する方法に，欠陥があるように考え，立位 による方法を試みて，その所見を手術所見と比較検討 してみると, 硬膜外造影法は, 非常に有益な検査法で あるという結論を得たので報告する。
方法

仙骨裂孔より $0.5 \%$ Xylocain $20 \mathrm{ml}$ を注入，約 5 分後, 頭側を $45^{\circ} \sim 50^{\circ}$ 挙上した立位の腹臥位におい て, 60\% Urographin $20 \mathrm{ml}$ を, 同部より注入する. 造影剂注入時, レ線テレビにてその上昇の様子および 放散痛を観察する. 注入後出来るだけ速やかに, 腰椎 4 方向のレ線撮影を行う.なお施行前に, ヨード過敏 テストおよびその問診を行う.

この方法により, 国立福岡中央病院整形外科におい て, 昭和 45 年 7 月以降, 坐骨神経痛または頑固な腰 痛を有する患者 66 例に，硬膜外造影を行った. 年令 は 15 才から 63 才まで平均 33 才である.

本法の利点とするところは，合併症がほとんどな く, 手技が比較的容易で, 少し慣れれば, 次に示す点 により，誰にであ所見の判読は容易である，すなわち 水平腹臥位に比して, 造影剂が腰椎下部に充満しやす 
いために，鮮明な像が得られること，神経根像が下位 より順に速やか汇出現するとと，などである。

症

例

症例1 21才男

主訴 腰痛㧍よび左下肢痛

現病歴 3 年前物を拾掞うとして，急に前かがみに なったところ，Hexenschuss を来たし，某医で 2 力 月間入院，骨盤率引をうけるあ腰痛は不変. 44 年 5 月 7 日当科受軖, 左根性坐骨神経痛ということで, 骨

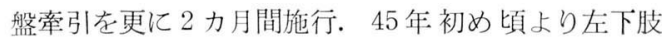
のしびれ感あり， 45 年 8 月 14 日再度当科受診， 45 年 9 月 4 日立位硬膜外造影を施行, 手術を勧好.

入院時所見 脊椎の変形 $(-)$, Lasegue 左 $(+)$, 腱反射正常, 左下腿外側加足背飞加外知覚鈍麻市 り, 筋萎縮 ( - , 筋力低下 ( - )

硬膜外造影所見 図 1 のごとく, $\mathrm{L}_{45}$ 問に久損像あ り.
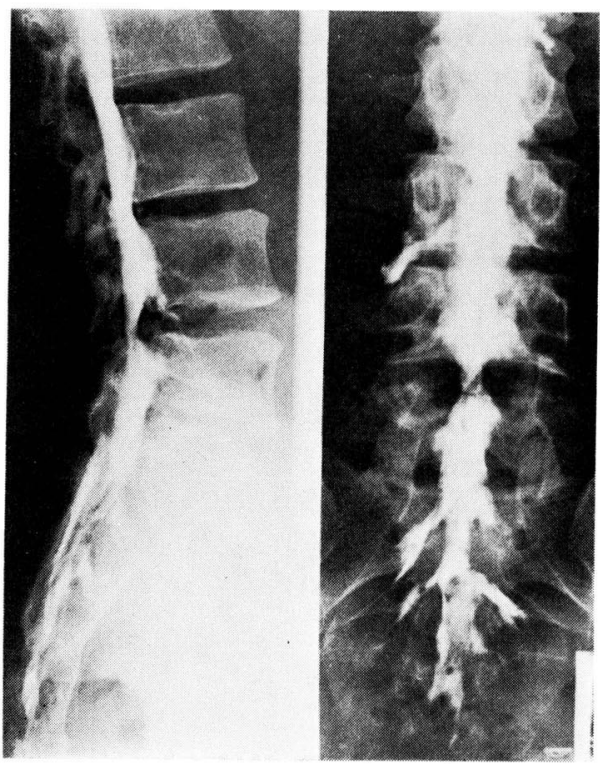

図 1 症例 1

手術所見 $\mathrm{L}_{45}$ 間左よりの中心沂くへルニアを認 め摘出した.

症例 238 才男

主訴 腰痛㧍よび右下肢痛

現病歴 約 1 年前より軽度の腰痛あり, 次第に強く なり右下肢痛が加わり，45 年 10 月 12 日より 勤務不
能となる。 45 年 10 月 28 日当科受診, 右根性坐骨神 経痛の䛦断のもとに，保存的治療老行う.

主訴の改善は，はかばかしくなく，46年 1 月 25 日

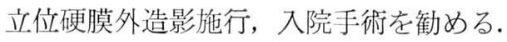

入院時所見 脊椎の変形 $(-)$, Lasegue 右 $(+)$, 腱反射正常, 右下腿外側加右足背に加け知覚鈍麻あ り, 筋萎縮 $(-)$, 右長拇趾伸展筋筋力低下 $(+)$.

硬膜外造影所見 図 2 のごよく, $\mathrm{L}_{5} \mathrm{~S}_{1}$ 間で，造影 剂が完全に止まり上方への拡がりが見られない．右側 よりに欠損像がみられる。

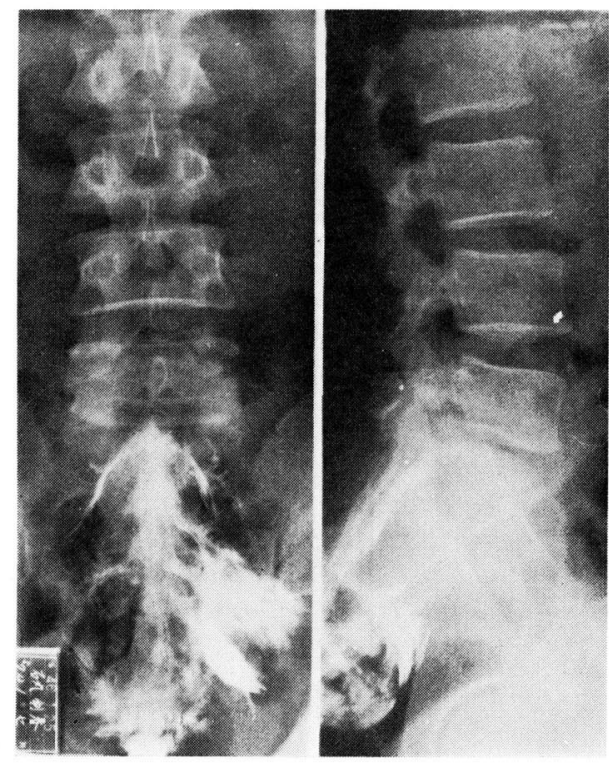

図 2 症例 2

于術所見 $\mathrm{L}_{5} \mathrm{~S}_{1}$ 間右方にヘルニアを認め, 摘出し た.

症例 $3 \longrightarrow 31$ 才男

主訴 前屈時の著明な腰痛

現病歴 約 1 年前より歩行時両下肢のしびれ感あ り. 45 年 1 月某医で腰痛症といわれ, 与薬, 注射, 骨 盤率引などをうけたが症状不変。次第に主訴が増悪し て来た. 46 年 3 月 5 日当科受䛦, 立位硬膜外造影を 施行. 椎間板へルニアが推定され, 手術を勧六院.

入院時所見 脊椎の変形 (一), Lasegue $(-)$, 腱 反射正常, 知覚鈍麻 $(-)$, 筋萎縮 ( $(-)$, 筋力低下 $(-)$.

硬膜外造影所見 図 3 のごよく, $\mathrm{L}_{45}$ 間に著明な欠 損像あり, 右側 $\mathrm{L}_{5}$ 神経根像の欠如が見られ, 中央部 


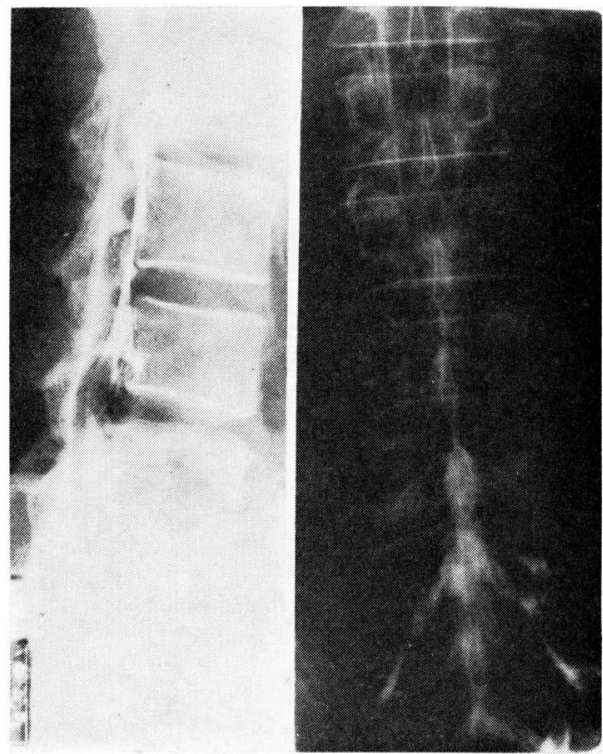

図 3 症例 3

のヘルニアが推定される.

手術所見 $\mathrm{L}_{45}$ 間中央部にヘルニア在認め摘出し た。

症例 4

29 才男

主訴腰痛扔よび左下肢痛

現病歴 約 4 年前より特に誘因なく腰痛を訴えてい る. 2 年前腰痛が増強し, 某医に 2 力月間入院, 骨盤 率引をうける屯症状不変. 45 年 9 月 18 日当科受診, 左根性坐骨神経痛の診断のもとに入院.

入院時所見 脊椎の変形 (一), Lasegue 左 $(+)$, 膝蓋腱反射正常, アキレス腱反射左低下, 左下腿から 足背に軽度の知覚鈍麻 $(+)$, 筋萎縮 $(-)$, 筋力低下 (一).

硬膜外造影所見 造影剂の上部への拡がりは容易 で，椎間に一致した欠損像が見られない.

手術所見， $\mathrm{L}_{45}$ 間左側の Love 氏手術でヘルニアを 認めない.

症例 5

18 才男

主訴 腰痛

現病歴 45 年 9 月ラグビーをした後, 腰痛を来た した. 疼痛は右下肢へ放散する. 某医に 23 日間入院, 骨盤旁引をうけたが，腰痛は不変，46 年 3 月 16 日右 大腿外側に知覚鈍麻があるのに気付いた. 46 年 3 月 24 日当科受診, 右根性坐骨神経痛の診断のもとに入
院を勧めた.

入院時所見 奉椎の変形 (一), Lasegue 右 (H), 腱反射正常, 右大腿外側飞知覚鈍麻 $(+)$, 筋萎縮 (一), 筋力低下 (一).

硬膜外造影所見 $\mathrm{L}_{3} \sim \mathrm{L}_{5}$ にかけて 線状の陰影欠損 あり，静脈瘤の存在を推定した。な推間に一致した 欠損像は認めない。

手術所見 $\mathrm{L}_{4.5} \mathrm{~S}_{1}$ にかけて, 中央より右側に静脈 瘤を認めた。ヘルニアは認めなかった。

症例 6 33才男

主訴 腰痛扢よび右下肢痛

現病歴 約 2 年前野球をしていて Hexenschuss 老 来たしたが自然治癒した. 45 年 9 月野球をしていて 再度腰痛を来たし, 某医でヘルニアといわれ，骨盤率 引をうけたが不変. 45 年 9 月 25 日当科受殓, 立位硬 膜外造影を施行， $\mathrm{L}_{45}$ 間椎間板へルニアを推定，手術 を唚めた。

入院時所見 $\mathrm{L}_{45}$ 間で右凸の側彎 $(+)$, Lasegue 右 (十), 腱反射正常, 知覚鈍麻 (一), 筋萎縮 (一), 筋力低下 (一).

硬膜外造影所見 造影剂の腰部への拡がりが極めて 遅く $\mathrm{L}_{4.5}$ 間通過中, 著明な右下肢への放散痛圭認め た. $\mathrm{L}_{45}$ 間に欠損像を認めた.

手術所見 $\mathrm{L}_{45}$ 間右にヘルニアを認め摘出した.

$$
\text { 結 び }
$$

先に述べたごとく，臨床的に理学的所見および神経 学的所見をほとんよ゙得られない場合にも，ヘルニアの 存在を手術的に確認することが，決して少なくない。 例えば，根症状のもっとも重要な所見である Lasegue 症候は， $\mathrm{L}_{34}$ ではその出現率が少なくまたいわゆる central disk herniation といわれる屯のでは, 高位 の如何にかかわらず，ただ項固な腰痛のみが持続す 万.

従って，以上述べたような立位による硬膜外造影法 は, 腰椎椎間板ヘルニアの診断には, 大変有益で確診 率の高い検査法であるといえる.

\section{追 加 九大 諸岡 正明}

硬膜外造影法は最近かなり広く行われるようになっ てきたが，その読影に関しては，まだいろいろと困難 なととが多い、私はそれを解決する一つの方法として 立体造影を行ないよい結果を得ている. 